\title{
The end of menthol cigarettes - missed opportunity or a great step toward decrease of lung cancer burden among women in Poland?
}

To the Editor,

on May $20^{\text {th }} 2020$, due to enforcement of the Directive 2014/40/EU, in Poland and other European Union (EU) countries, ban on selling menthol cigarettes came into force. This long-waited law raises health hopes - in particular for Polish female smokers. In accordance to the latest data sourced from the National Cancer Registry in Poland [1], in 2017 lung cancer was main cause of cancer deaths, both - in men and women populations and has contributed respectively to 15499 (ASW $=45,3)$ and 7825 (ASW $=17,8)$ deaths. Despite the beneficial changes in smoking patterns among Polish men in the last period of time (about 9 percentage points (pp) less smokers in 2019 in comparison with 2012 [2]) epidemiological trends of lung cancer suggest that there is no parallel and favorable change in women population as well. 2017 was another year (since 2007) where number of deaths among women caused by lung cancer was higher in comparison with breast cancer which is the most frequent one in terms of incidence. Adopted law on menthol cigarettes ban can be considered as one of the greatest chances since years to change this phenomenon and to reverse this adverse trend. Although the data on menthol cigarettes consumption in Poland is scarce, there are some evidence that women smoke menthols more eager than men ( $8.4 \%$ vs. $2.5 \%)$. In the same study authors indicate that menthol smokers feel greater reward and satisfaction during smoking in comparison with regular smokers [3]. Moreover, some of the observations suggest also that menthol cigarettes are perceived by women as more socially acceptable than non-menthol ones [4]. Other studies stress higher addictive potential of the flavored cigarettes as well [5]. At the same time there are also certain evidence of high effectiveness of menthol cigarettes ban in reducing or even quitting smoking in menthol smokers group [4].

Despite the right direction of changes in anti-tobacco law, there is an emerging question on pace and complexity of implemented solutions. Discussed ban does not include e-cigarettes and heated tobacco products. Additionally, period between adoption and enforcement of the law (about 6 years) seems to be much too long. This gap gave tobacco industry the opportunity to prepare for changes and the chance for development of the new tobacco products for women and young people - main menthol cigarettes users. From this perspective, the chance for favorable changes in women's health behaviors seems to be not fully taken or even lost. However, in the coming years ban on slim cigarettes selling will force into life as well. This particular type of cigarettes has been designed also especially for women, therefore there is a hope that jointly with excise tax increase, these regulations will contribute to decrease in the lung cancer burden among Polish women.

Paweł Koczkodaj, Magdalena Cedzyńska, Joanna Didkowska

Cancer Epidemiology and Primary Prevention Department, Maria Sklodowska-Curie National Research Institute of Oncology, Warsaw e-mail:pawel.koczkodaj@pib-nio.pl

\section{References}

1. Didkowska J, Wojciechowska U, Czaderny K, Olasek P, Ciuba A. Nowotwory złośliwe w Polsce w 2017 roku., Warszawa 2019.

2. Centrum Badań Opinii Społecznej, Komunikat z Badań nr 104/2019 Palenie papierosów, ISSN 2353-5822, Centrum Badań Opinii Społecznej, Komunikat z Badań nr 104/2019 Palenie papierosów, ISSN 2353-5822 2019.

\section{How to cite:}

Koczkodaj P, Cedzyńska M, Didkowska J. The end of menthol cigarettes - missed opportunity or a great step toward decrease of lung cancer burden among women in Poland? NOWOTWORY J Oncol 2020; 70: 161-162. 
3. Pinkas J, Kaleta D, Zgliczyński WS, et al. The Prevalence of Tobacco and E-Cigarette Use in Poland: A 2019 Nationwide Cross-Sectional Survey. Int J Environ Res Public Health. 2019; 16(23), doi: 10.3390/ijerph16234820, indexed in Pubmed: 31801221.

4. Kaleta D, Usidame B, Szosland-Fałtyn A, et al. Use of flavoured cigarettes in Poland: data from the global adult tobacco survey (2009-2010). BMC
Public Health. 2014; 14: 127, doi: 10.1186/1471-2458-14-127, indexed in Pubmed: 24502292.

5. Wickham RJ. How Menthol Alters Tobacco-Smoking Behavior: A Biological Perspective. Yale J Biol Med. 2015; 88(3): 279-287, indexed in Pubmed: 26339211. 